\title{
Associations between North Atlantic right whales and their prey, Calanus finmarchicus, over diel and tidal time scales
}

\author{
Mark F. Baumgartner ${ }^{1,5, *}$, Tim V. N. Cole ${ }^{2}$, Robert G. Campbell ${ }^{3}$, \\ Gregory J. Teegarden ${ }^{4}$, Edward G. Durbin ${ }^{3}$ \\ ${ }^{1}$ College of Oceanic and Atmospheric Sciences, Oregon State University, 104 Ocean Administration Building, Corvallis, \\ Oregon 97331, USA \\ ${ }^{2}$ National Marine Fisheries Service, Northeast Fisheries Science Center, 166 Water Street, Woods Hole, Massachusetts 02543, USA \\ ${ }^{3}$ Graduate School of Oceanography, University of Rhode Island, Narragansett, Rhode Island 02882, USA \\ ${ }^{4}$ Saint Joseph's College, 278 Whites Bridge Road, Standish, Maine 04084, USA
}

${ }^{5}$ Present address: Biology Department, MS \#33, Woods Hole Oceanographic Institution, Woods Hole, Massachusetts 02543, USA

\begin{abstract}
Temporal variability in the distribution and abundance of North Atlantic right whales Eubalaena glacialis and their copepod prey, late-stage Calanus finmarchicus, was monitored at an oceanographic station in Grand Manan Basin of the lower Bay of Fundy for $29 \mathrm{~h}$ on 2 separate occasions. The vertical distribution of C. finmarchicus was measured at $1 / 2 \mathrm{~h}$ intervals with an optical plankton counter (OPC) and at 6 or $12 \mathrm{~h}$ intervals with a MOCNESS. Right whale abundance was estimated from periodic point scans. Late-stage C. finmarchicus exhibited diel vertical migration in the upper $100 \mathrm{~m}$ of the water column, but the bulk of the population remained at depths below $100 \mathrm{~m}$ throughout both the day and night and was likely in diapause. Diel vertical migration is unlikely to be influenced by right whales, but may instead be motivated by abundant, near-surface food resources and avoidance of visual predators. Right whale sighting rate was correlated with OPCdetected C. finmarchicus fifth copepodite (C5) abundance at mid-depths (90-140 m); variability in both right whale sighting rate and C. finmarchicus $\mathrm{C} 5$ abundance in this depth stratum appeared to have similar periodicity to that of the tide. Energetic considerations suggest that right whales continue to feed on deep, diapausing layers of $C$. finmarchicus during the night, but the occasional presence of exploitable near-surface concentrations of $C$. finmarchicus suggests that nighttime near-surface feeding might sometimes occur.
\end{abstract}

KEY WORDS: Right whale $\cdot$ Eubalaena glacialis $\cdot$ Calanus finmarchicus $\cdot$ Diel vertical migration · Tides $\cdot$ Gulf of Maine $\cdot$ Bay of Fundy $\cdot$ Optical plankton counter

\section{INTRODUCTION}

The North Atlantic right whale Eubalaena glacialis feeds primarily upon the calanoid copepod Calanus finmarchicus. It accomplishes this by filtering seawater through very fine baleen that can retain large copepods efficiently (Mayo et al. 2001). Because there are only roughly 300 individuals remaining in this endangered population (IWC 2001), right whale predation probably has a negligible effect on $C$. finmarchicus population dynamics. However, right whale predation on older copepodite stages of $C$. finmarchicus must be intense in some regions where right whales aggregate annually, such as Cape Cod Bay in the late winter (Watkins \& Schevill 1976, Mayo \& Marx 1990), Great South Channel in the spring (Wishner et al. 1988, 1995, Beardsley et al. 1996) and the lower Bay of Fundy during the summer and early fall (Murison \& Gaskin 1989, 
Woodley \& Gaskin 1996, Baumgartner et al. 2003 this issue). The reliability of both right whale and $C$. finmarchicus aggregations in these regions provides an opportunity to study the unique trophic relationship between this predator and prey.

Studies that have employed net sampling near right whales in the lower Bay of Fundy suggest that right whales feed on Calanus finmarchicus fifth copepodites (C5) (Murison \& Gaskin 1989, Woodley \& Gaskin 1996, Baumgartner et al. 2003). Right whales forage during the day on $C$. finmarchicus $\mathrm{C} 5$ that aggregate in discrete layers deep in the water column just above a bottom mixed layer (Baumgartner \& Mate 2003 this issue). Nighttime vertical migration to the surface by the copepods in these deep layers would have important implications for right whales. Surface feeding by the whales would be expected to have energetic benefits since transit time to shallower food resources is reduced. For a constant dive duration, reduced transit time increases feeding time, so comparatively more energy can potentially be acquired per dive when feeding near the surface than at depth.

Surface feeding may also be accompanied by costs to the whales, however. Right whale exposure to the natural toxins that cause paralytic shellfish poisoning (PSP) may be enhanced by feeding on near-surface aggregations of Calanus finmarchicus that have significantly higher PSP toxin levels than deeper copepods (Durbin et al. 2002). These toxins are produced by the dinoflagellate Alexandrium fundyense, which is present in the surface waters of the lower Bay of Fundy during the summer and early fall (Martin \& White 1988, Townsend et al. 2001) and is consumed by C. finmarchicus (Turriff et al. 1995, Teegarden et al. 2001). Feeding on these contaminated $C$. finmarchicus may have detrimental effects on right whale respiratory capabilities (Geraci 1989). The North Atlantic right whale population also experiences significant mortality due to ship strikes (Kraus 1990, Kenney \& Kraus 1993, Knowlton \& Kraus 2001), and an increase in the time spent at the surface while feeding there would be expected to increase the risk of collision.

To better understand temporal variability in prey availability for right whales and the potential response of Calanus finmarchicus to right whale predation, we occupied oceanographic sta- tions in the lower Bay of Fundy at which simultaneous diel vertical migration (DVM) studies and periodic point scans of right whales were conducted. The vertical distribution of $C$. finmarchicus C5 was monitored with a vertically profiled optical plankton counter (OPC) deployed every half hour and a multiple opening-closing net and environmental sensing system (MOCNESS) towed every 6 or $12 \mathrm{~h}$. The vertical distributions of other late-stage $C$. finmarchicus (C4 and adults) were also monitored with the MOCNESS. These data were used to investigate vertical migration by $C$. finmarchicus and associated variability in right whale abundance over diel and tidal time scales.

\section{MATERIALS AND METHODS}

Two stations were occupied by NOAA ship 'Albatross IV' in Grand Manan Basin of the lower Bay of Fundy during the summer of 2001 (Fig. 1). The first

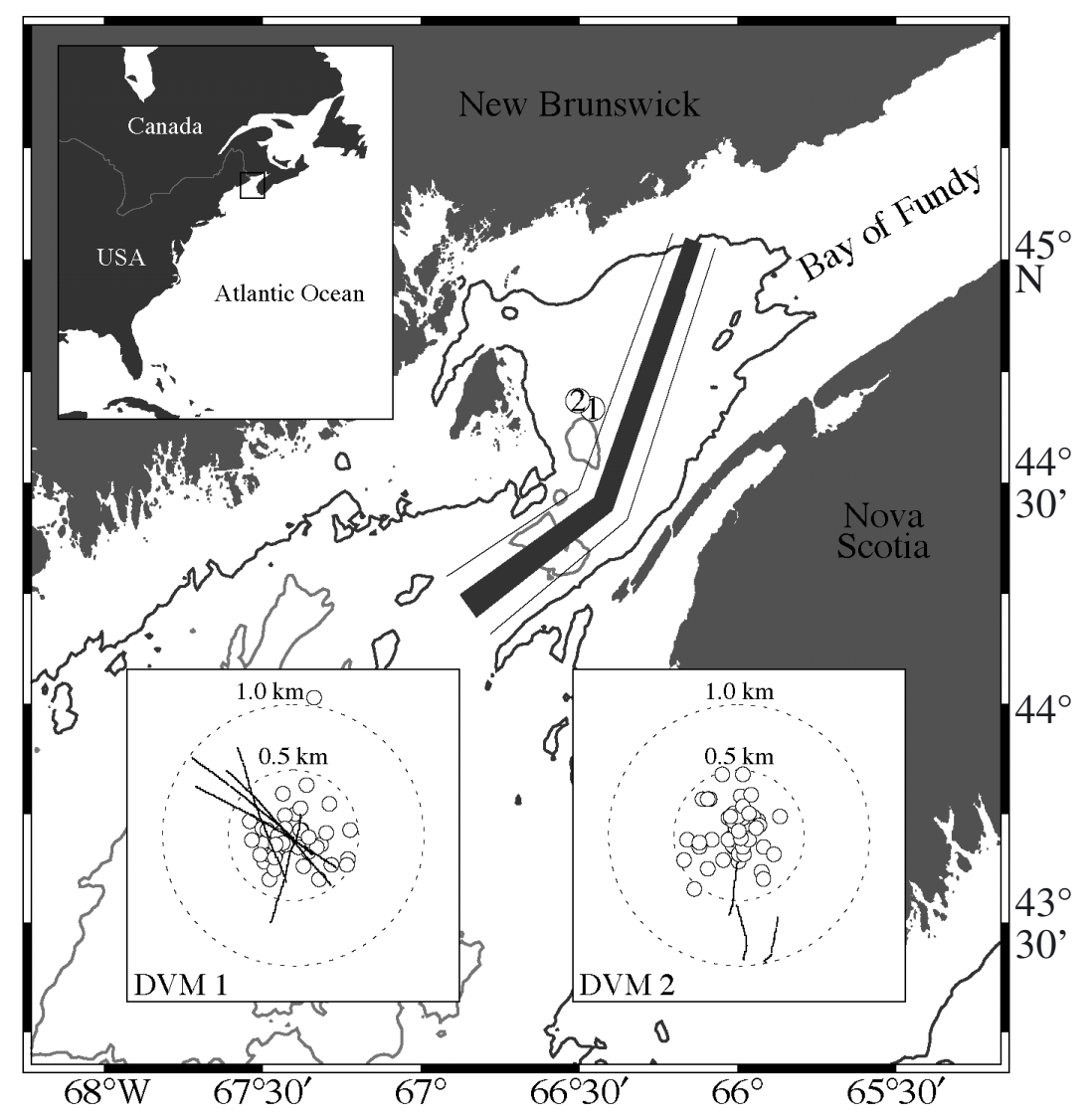

Fig. 1. Map of study area. (1),(2): Location of each station in the lower Bay of Fundy. Shipping lanes that passed through this region at the time of the study are also shown (they have since been changed). Location of the study area along the eastern seaboards of the United States and Canada shown in the upper left inset. Optical plankton counter (OPC) cast locations (O) and MOCNESS tow paths (lines) relative to each station (center of plot) shown in the lower insets. DVM: diel vertical migration 
study (DVM 1) took place at $44^{\circ} 40.0^{\prime} \mathrm{N}, 66^{\circ} 27.5^{\prime} \mathrm{W}$ on 29 and 30 July. This location was selected because right whales had been consistently sighted there in the 2 previous summers. The second study (DVM 2) was conducted on 31 July and 1 August at a location $\left(44^{\circ} 41.1^{\prime} \mathrm{N}, 66^{\circ} 30.3^{\prime} \mathrm{W}\right)$ where whales were initially present and abundant. The stations for DVM 1 and 2 were occupied for 29.2 and $28.7 \mathrm{~h}$, respectively. A Focal Technologies model OPC-1T OPC (Herman $1988,1992)$ was deployed in a vertical cast at a nominal descent speed of $1.0 \mathrm{~m} \mathrm{~s}^{-1}$ every 30 min during each study. The OPC provided the vertical distribution of particles ranging in size from 0.25 to $20 \mathrm{~mm}$. The abundance of particles between 1.5 and $2.0 \mathrm{~mm}$ equivalent circular diameter was computed over $5 \mathrm{~m}$ depth strata and converted to Calanus finmarchicus C5 abundance using the calibration equation of Baumgartner (2003). Vertical migration rates were determined when coherent changes in the distribution of $C$. finmarchicus $\mathrm{C} 5$ were observed in a portion of the water column. The depths of peak abundance during a migration period were regressed against time and the slope of the linear regression is reported as the migration rate. Only depths with peak abundances greater than 100 copepods $\mathrm{m}^{-3}$ were used in the regression. Day and night were defined as the periods bracketed by the times of sunset and sunrise as calculated from equations of solar elevation angle for each station (Kirk 1994). The beginning and end of nautical twilight were computed as the times when the solar elevation angle was $-12^{\circ}$ (i.e. $12^{\circ}$ below the horizon) (Bowditch 1995).

At 6 (DVM 1) or 12 (DVM 2) h intervals, a MOCNESS (Wiebe et al. 1976, 1985) equipped with $150 \mu \mathrm{m}$ mesh nets was towed through the station. The MOCNESS sampled 5 contiguous depth strata from approximately $10 \mathrm{~m}$ above the bottom to the surface. These strata were chosen after reviewing OPC data collected prior to the first MOCNESS tow in each DVM study. Samples were preserved in a $10 \%$ formalin-seawater solution and subsampled in the laboratory. All Calanus finmarchicus copepodite stages were enumerated in the subsamples, and the abundance of each stage was estimated from these counts, the subsample volume and the volume of seawater filtered by the net. The abundance data from the MOCNESS tows were not used to construct the OPC calibration equation of Baumgartner (2003).

Periodic visual surveys for right whales were conducted during each DVM study from the bow of NOAA Ship 'Albatross IV'. Observers searched for right whales using binoculars and the naked eye during several discrete, daytime survey periods that lasted an average of $34 \mathrm{~min}$ (range: $17-50 \mathrm{~min}$ ). Scans of 3 to 4 min were conducted every 10 to 15 min during a survey period. Sighting rates were computed as the total number of whales sighted within $2000 \mathrm{~m}$ of the ship during a survey period divided by the duration of the survey period. Repeat sightings of individual whales were undoubtedly made during successive scans within a survey period, so the sighting rate can only be considered a relative measure of abundance.

The relationship between right whale sighting rates and OPC-derived Calanus finmarchicus C5 abundance was examined using correlation analysis. Since C. finmarchicus C5 abundance could be computed over multiple depth strata and we had no formal hypothesis addressing in which depth stratum C. finmarchicus $\mathrm{C} 5$ abundance might influence right whale distribution, we examined correlations between right whale sighting rates and $C$. finmarchicus $\mathrm{C} 5$ abundance computed over all possible depth strata. The minimum depth for each depth stratum was systematically varied from 0 to $200 \mathrm{~m}$ in $5 \mathrm{~m}$ intervals. The maximum depth for each depth stratum was systematically varied from the minimum depth to $200 \mathrm{~m}$ in $5 \mathrm{~m}$ intervals. For each survey period and depth stratum, C. finmarchicus C5 abundance was averaged over the 3 OPC casts spanning the survey period.

Predictions of local tidal currents were acquired from Tides \& Currents software (version 2.0) (Nautical Software 1996) based on U.S. National Oceanic and Atmospheric Administration and Canadian Hydrographic Service harmonic constants. The software provided estimates of current speeds and only 2 possible current directions $\left(40^{\circ}\right.$ at flood and $235^{\circ}$ at ebb) every $30 \mathrm{~min}$ at $44^{\circ} 44^{\prime} \mathrm{N}, 66^{\circ} 15^{\prime} \mathrm{W}$. The tidal currents were integrated over time to estimate the displacement of a passive particle relative to this location. The phase of the tidal predictions was verified by comparing the tidal displacement to the temporal variability in water depth measured continuously by the NOAA Ship 'Albatross IV' scientific echo sounder (Simrad EK-500). The phases of the predictions and observations were in very good agreement such that, for instance, times of maximum tidal displacements coincided with observed periods of high and low water. The predicted times of high tide, low tide, maximum flood currents and maximum ebb currents were therefore considered accurate. The predicted current magnitude (and hence the absolute magnitude of the tidal displacement), however, was not considered accurate, since wind, baroclinic and residual barotropic effects are not included in the predictions.

\section{RESULTS}

DVM 1

The MOCNESS data suggested that the upper $20 \mathrm{~m}$ of the water column contained low abundances of 

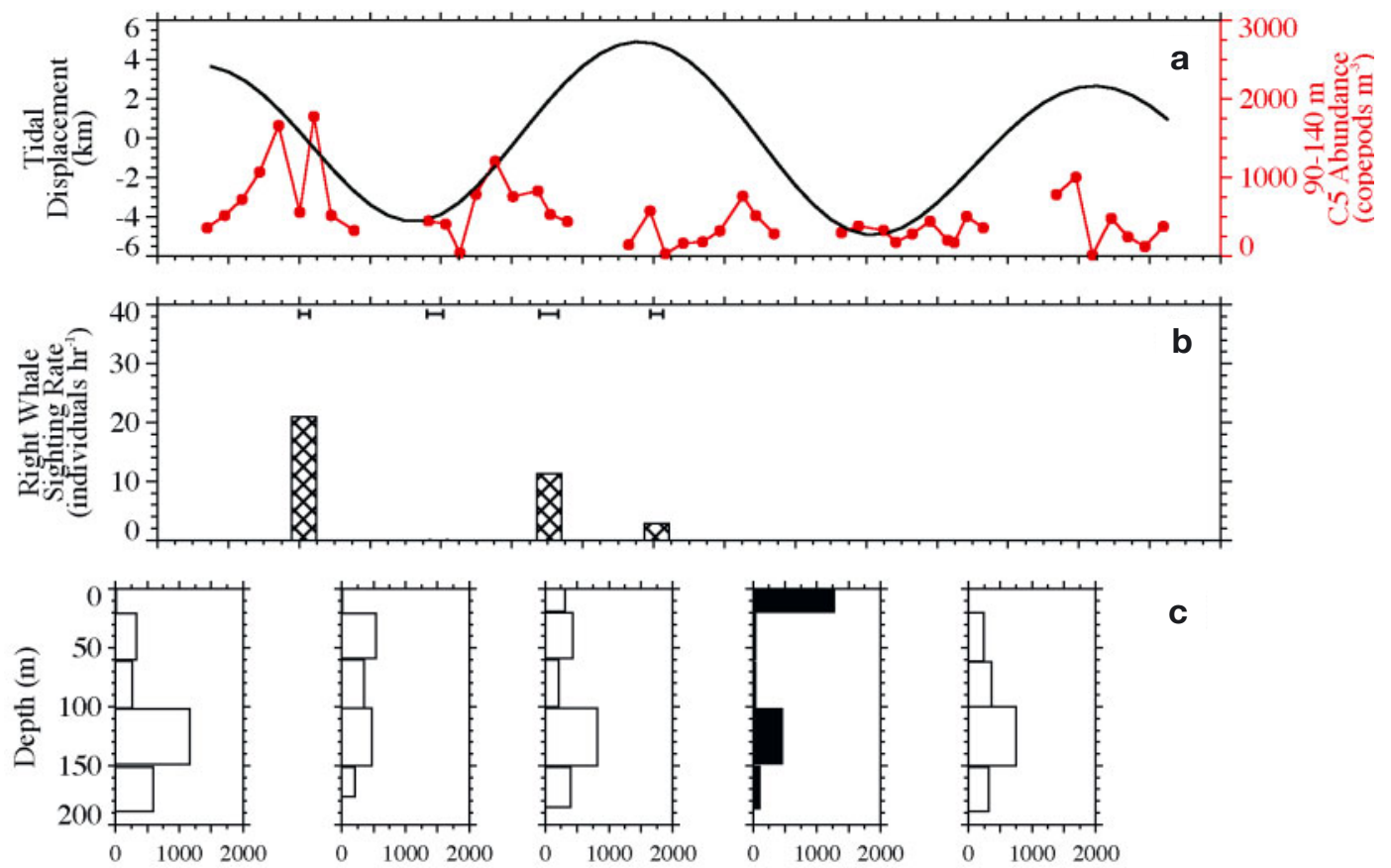

C

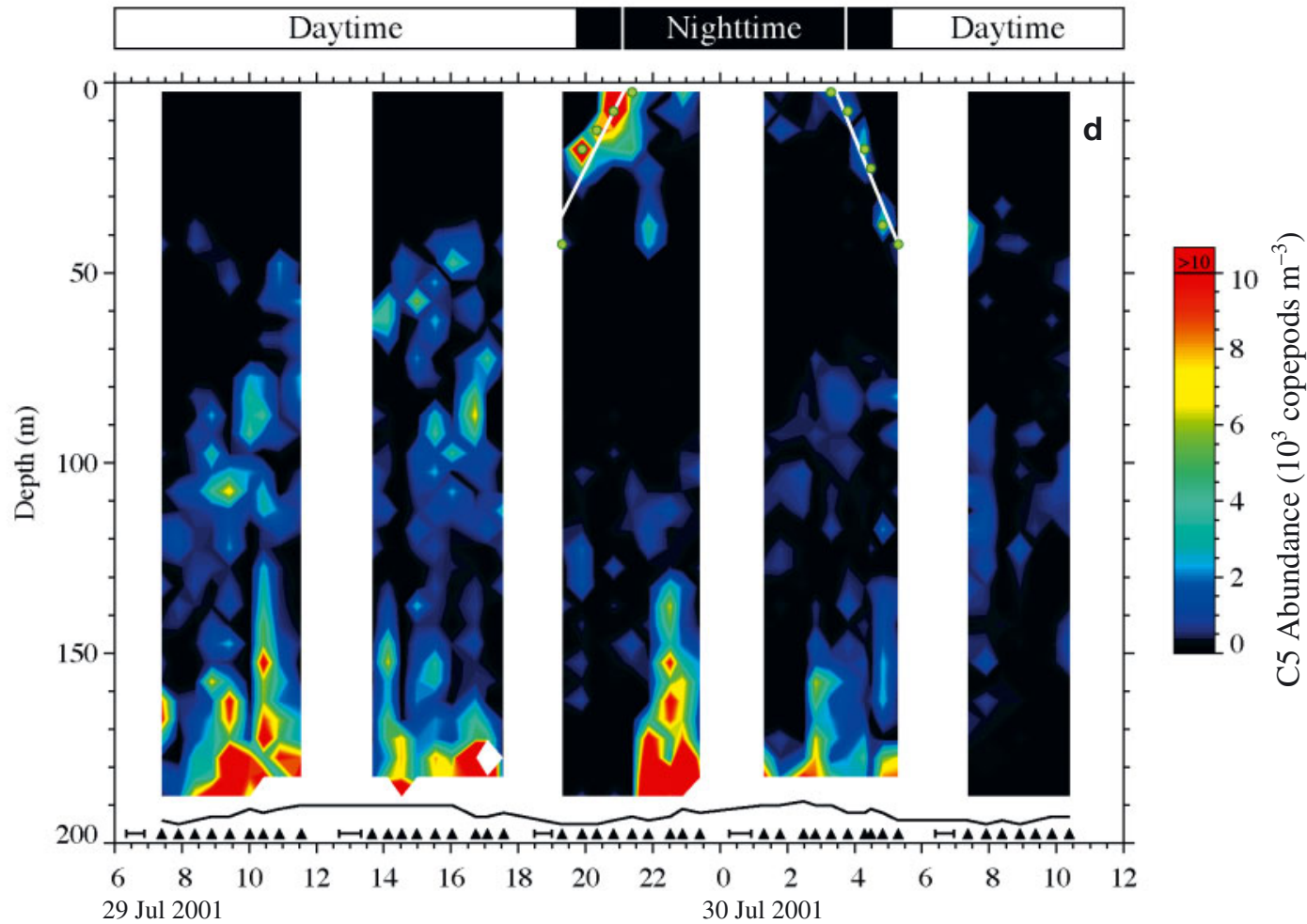

Time of day (h)

Fig. 2. Eubalaena glacialis and Calanus finmarchicus. (a) Tidal displacement during DVM 1 showing times of high tide (local maximums) and low tides (local minimums). OPC-detected C. finmarchicus C5 abundance between 90 and $140 \mathrm{~m}$ shown in red. (b) Right whale sighting rate within $2000 \mathrm{~m}$ of the ship. Bars just below top axis indicate survey periods. (c) Vertical distribution of C. finmarchicus $\mathrm{C} 5$ from the MOCNESS tows (copepods $\mathrm{m}^{-3}$ ). Individual plots are aligned over their respective tow periods in the accompanying plots. (d) Time evolution of OPC-detected C. finmarchicus C5 vertical distribution. Thick line at 190 to $195 \mathrm{~m}$ represents the bottom; $(\mathbf{\Lambda})$ and $(\longmapsto)$ are times when respective OPC casts and MOCNESS tows were conducted. $\left({ }^{\circ}\right)$ Peaks in abundance in the upper $60 \mathrm{~m}$ at dusk and dawn. Linear regressions from which the migration rates were calculated are also shown (see 'Materials and methods'). Day/night periods and the start/end of nautical twilight (vertical white lines) are indicated above (d). Plots (a), (b) and (d) all have the same time axis (shown in d). Time axes are in Atlantic Standard Time 
Calanus finmarchicus C5 for most of the daylight hours; however, the OPC data indicated that $C$. finmarchicus $\mathrm{C} 5$ abundance was low over the upper $40 \mathrm{~m}$ of the water column during this time (Fig. 2). OPCdetected C. finmarchicus C5 inhabiting depths of 40 to $100 \mathrm{~m}$ began migrating toward the surface within the half-hour prior to sunset at a rate of $0.50 \mathrm{~cm} \mathrm{~s}^{-1}(\mathrm{n}=5$, $95 \% \mathrm{CI}=0.12$ to 0.87 ). The data from the MOCNESS tow at 18:30 h suggested that some C. finmarchicus C5 appeared in the upper $20 \mathrm{~m}$ well before sunset (Fig. 2). The OPC-detected migrating layer reached the surface waters $(<5 \mathrm{~m})$ at the beginning of nautical twilight. The dusk migration resulted in very low nighttime abundances in the depth stratum between 20 and 70-90 m. Within the half-hour before nautical twilight ended, $C$. finmarchicus $\mathrm{C} 5$ left the surface waters, migrated downward at $0.60 \mathrm{~cm} \mathrm{~s}^{-1}(\mathrm{n}=6,95 \% \mathrm{CI}=0.42$ to 0.79 ) and reoccupied depths at or below $40 \mathrm{~m}$ by sunrise. The MOCNESS data indicated that $C$. finmarchicus $\mathrm{C} 4, \mathrm{C} 5$ and adult females (C6F) all vertically migrated into and out of the surface waters: C4, C5 and C6F abundance in the upper $20 \mathrm{~m}$ averaged 213, 103 and 2 copepods $\mathrm{m}^{-3}$ during the daytime and 467, 1288 and 97 copepods $\mathrm{m}^{-3}$ during the nighttime, respectively (Fig. 3). A deeper population of $C$. finmarchicus C5 occupying depths between 100 and $150 \mathrm{~m}$ did not vertically migrate. The average OPC-derived observations above $150 \mathrm{~m}$ were corroborated by the MOCNESS results (Fig. 3c,d).

OPC-detected particle abundances in the size range overlapping that of Calanus finmarchicus C5 were very high at times near the bottom (Fig. 2); however, it is unclear if these particles were in fact $C$. finmarchicus C5. The MOCNESS tows did not indicate that large aggregations of C. finmarchicus C5 existed near the bottom (Fig. 3c,d). The particle size distribution near the bottom is also inconsistent with the presence of C. finmarchicus C5 (Fig. 4). In waters with high C. finmarchicus C5 abundance, the particle size distribution is expected to be modal at approximately $1.55 \mathrm{~mm}$ (Baumgartner 2003). This modal peak can be readily observed in the average particle size distributions in the surface at night (Fig. 4a), between 40 and $100 \mathrm{~m}$ during the day (Fig. 4b) and between 100 and $130 \mathrm{~m}$ at all hours (Fig. 4c). No modal peak is apparent in the waters near the bottom (Fig. 4d). Moreover, the times of high particle abundance coincide with the times of maximum flood and ebb currents, which suggests that the particles detected by the OPC near the bottom may be detritus or sediment that has been resuspended by strong tidal flow.

\section{DVM 2}

Diel vertical migration was also observed in the upper water column $(<80 \mathrm{~m})$ during DVM 2. The OPC detected an aggregation of Calanus finmarchicus C5 residing at approximately $40 \mathrm{~m}$ depth during the daytime that migrated to the surface at night (Fig. 5, Fig. 6c,d). As was the case during DVM 1, upward
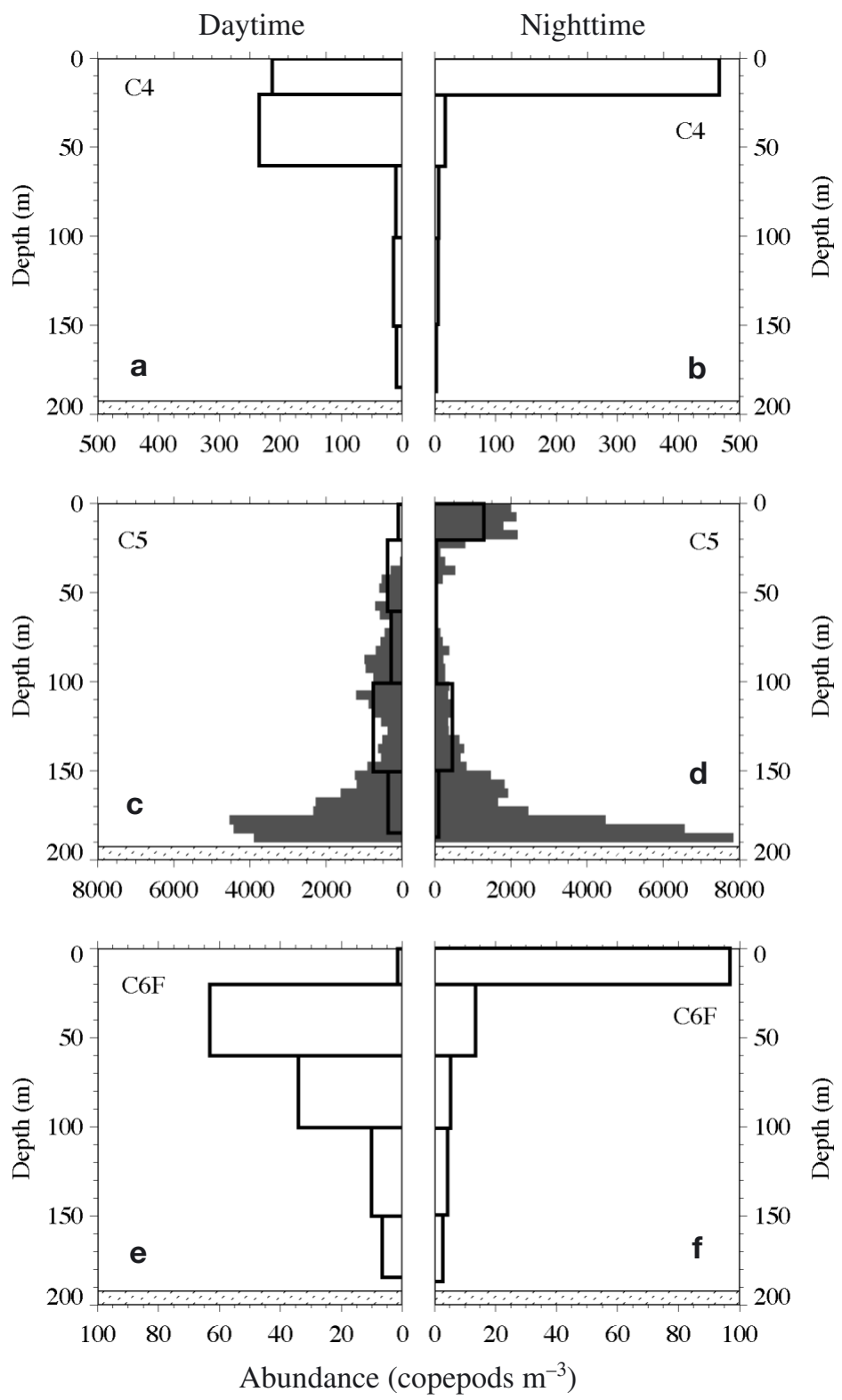

Fig. 3. Calanus finmarchicus. Vertical distribution of $(\mathrm{a}, \mathrm{b}) \mathrm{C} 4,(\mathrm{c}, \mathrm{d}) \mathrm{C} 5$ and $(\mathrm{e}, \mathrm{f})$ adult females (C6F) averaged over all daytime $(\mathrm{a}, \mathrm{c}, \mathrm{e})$ and nighttime $(b, d, f)$ MOCNESS tows during DVM 1. $(c, d)$ Average OPC-derived, daytime and nighttime vertical distributions of $C$. finmarchicus $\mathrm{C} 5$ shown as gray bars. Bottom indicated by the hatched area. Note that the apparent high abundance of $C$. finmarchicus C5 detected near the bottom by the OPC is likely due to resuspended sediments or detritus (see 'Results: DVM 1') 

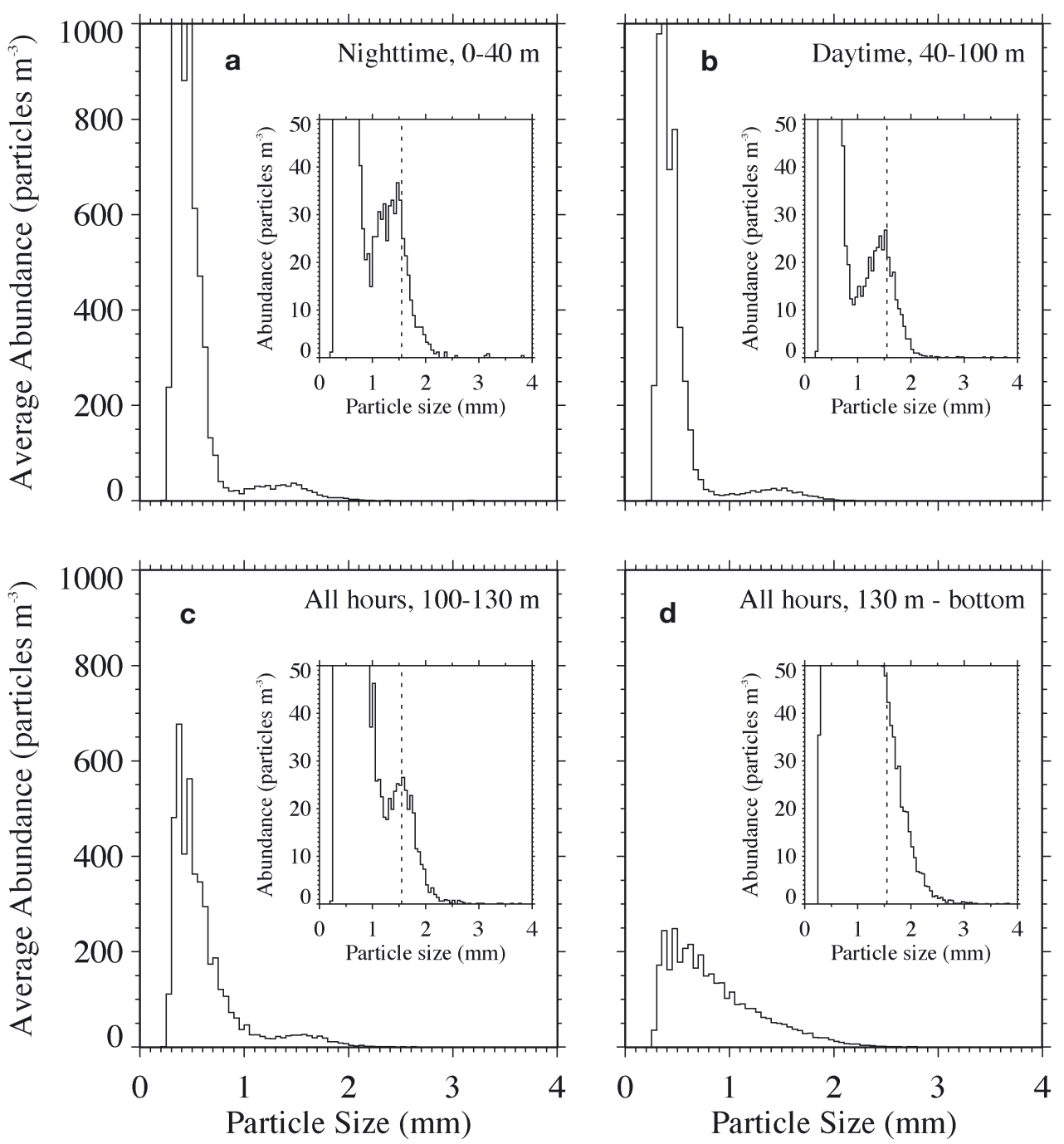

Fig. 4. Average particle size distributions for OPC data collected during DVM 1 (a) between 0 and $40 \mathrm{~m}$ at night, (b) between 40 and $100 \mathrm{~m}$ during the day, (c) between 100 and $130 \mathrm{~m}$ during all hours and (d) between $130 \mathrm{~m}$ and the bottom during all hours. Insets show details of average particle distributions between 0 and 50 particles $\mathrm{m}^{-3}$. Dotted line in each inset indicates the expected mode for Calanus finmarchicus C5 (1.55 mm) from Baumgartner (2003)

migration began in the half-hour prior to sunset and the migrating layer reached the surface $(<5 \mathrm{~m})$ at the beginning of nautical twilight. The upward migration rate of OPC-detected C. finmarchicus C5 $\left(0.67 \mathrm{~cm} \mathrm{~s}^{-1}\right.$, $\mathrm{n}=5,95 \% \mathrm{CI}=0.46$ to 0.89 ) was not significantly different from that observed during DVM 1. There were too few resolvable local peaks in abundance to adequately determine the timing or rate of the downward migration at dawn. A substantial portion of the C. finmarchicus C5 population resided below $80 \mathrm{~m}$ during both the daytime and nighttime. Local peaks in this depth stratum were observed well above the bottom with the exception of a single cast that occurred soon after dawn. The data from this cast had characteristics similar to those observed near the bottom during DVM 1 (e.g. a size distribution similar to Fig. 4 d, occurrence at the bottom during maximum tidal currents), so this cast may have also captured a resuspension event. The MOCNESS data corroborated the diel vertical migra- tion in the upper water column and the presence of the more abundant deep layer of C. finmarchicus C5 (Fig. 6c,d). These data also indicated vertical migration into and out of the surface waters by $C$. finmarchicus C4 and C6F as well: C4, C5 and C6F abundance in the upper $20 \mathrm{~m}$ averaged $0.3,1.1$ and 0.3 copepods $\mathrm{m}^{-3}$ during the daytime and 34, 135 and 28 copepods $\mathrm{m}^{-3}$ during the nighttime, respectively (Fig. 6). Agreement between the average OPC-derived C. finmarchicus C5 abundance estimates and those of the MOCNESS for all sampled depths was very good (Fig. 6c,d).

\section{Right whale abundance}

Significant correlations $(\mathrm{p}<0.05)$ occurred between right whale sighting rates and OPC-derived Calanus finmarchicus C5 abundance computed over depth strata having minimum depths of 65 to $110 \mathrm{~m}$ and max- 
imum depths of 115 to $160 \mathrm{~m}$. The maximum correlation occurred when OPC-derived C. finmarchicus C5 abundance was computed between 90 and $140 \mathrm{~m}(\mathrm{n}=$ 10, $\mathrm{r}=0.731, \mathrm{p}=0.016$; Fig. 7). There appears to be a single outlier from DVM 2 (survey effort on 31 July,
18:10 to $18: 53 \mathrm{~h} \mathrm{AST}$ ) that is characterized by a high sighting rate and a low C. finmarchicus C5 abundance (Fig. 7). The C. finmarchicus C5 abundance from 90 to $140 \mathrm{~m}$ was quite variable around the time of this survey, which may be the result of spatial heterogeneity
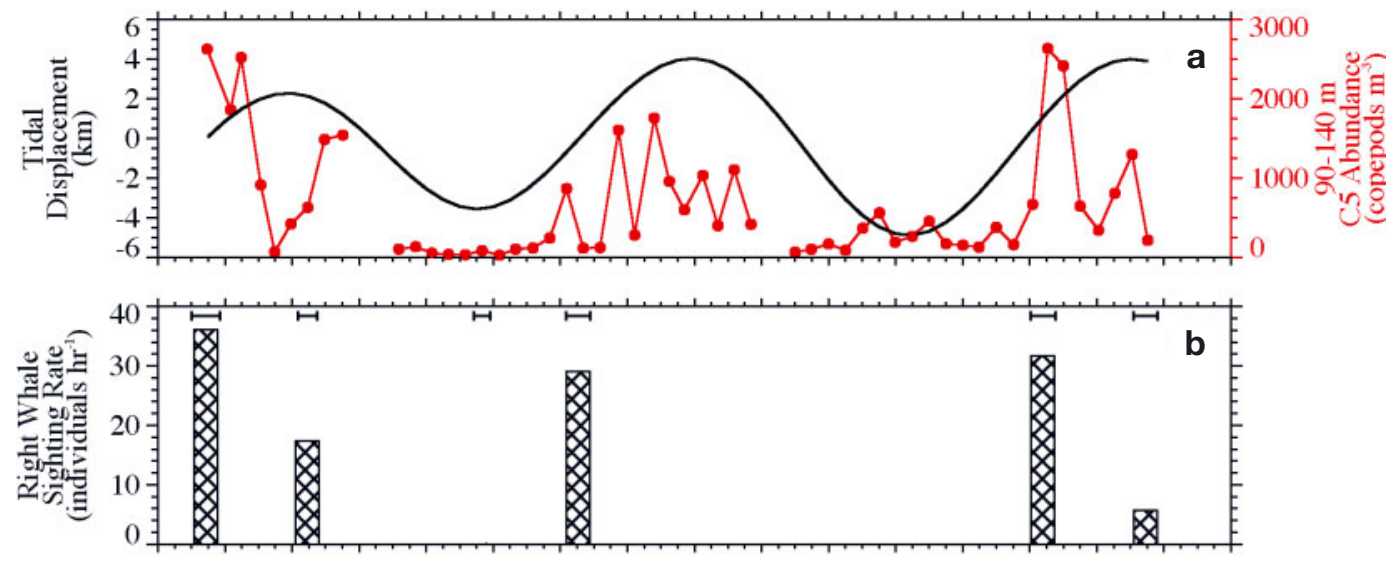

c
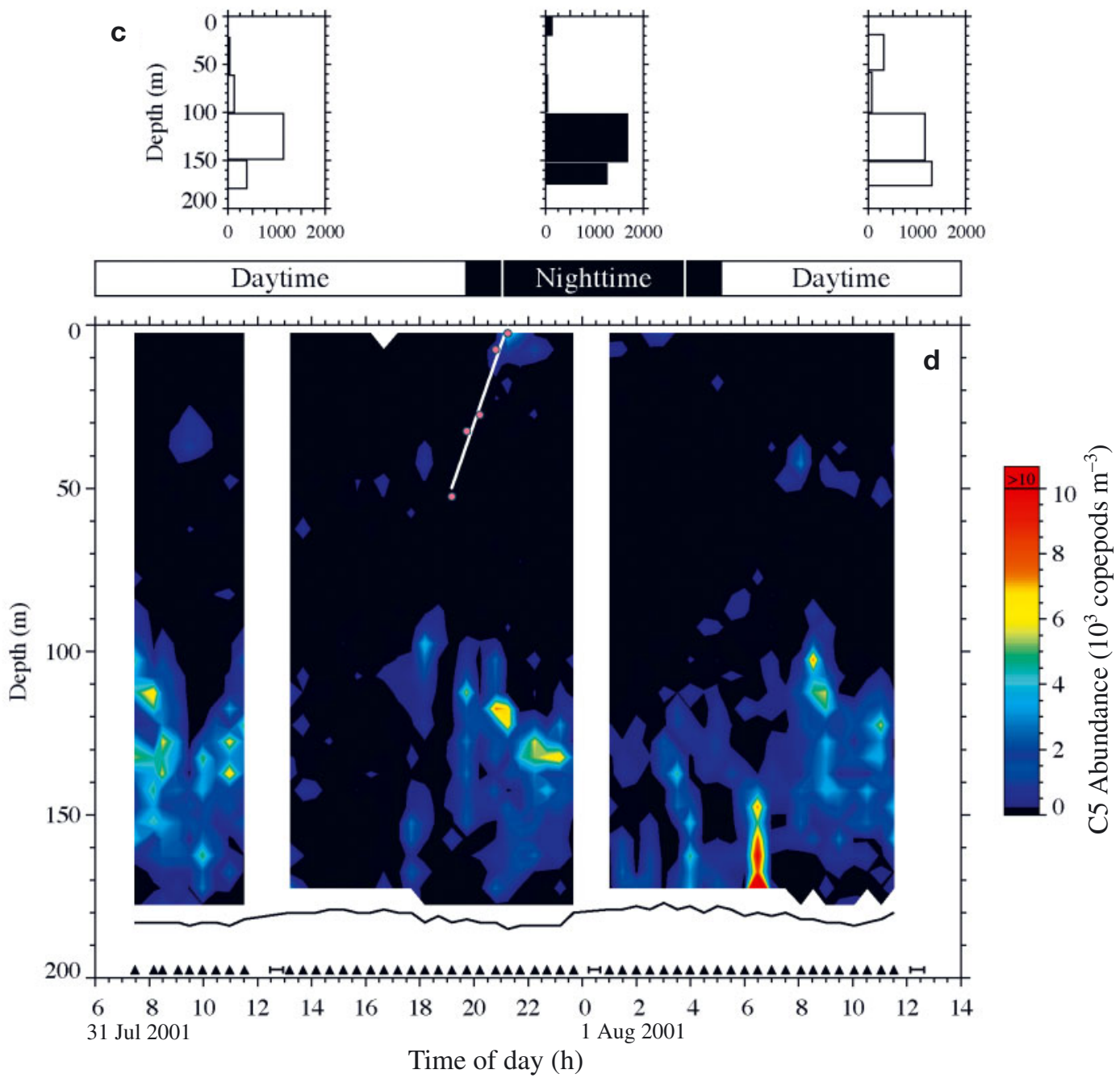

Fig. 5. Eubalaena glacialis and Calanus finmarchicus. Results from DVM 2. Axes and labels as in Fig. 2. Rate of downward migration at dawn was not estimated (see 'Results: DVM 2') 

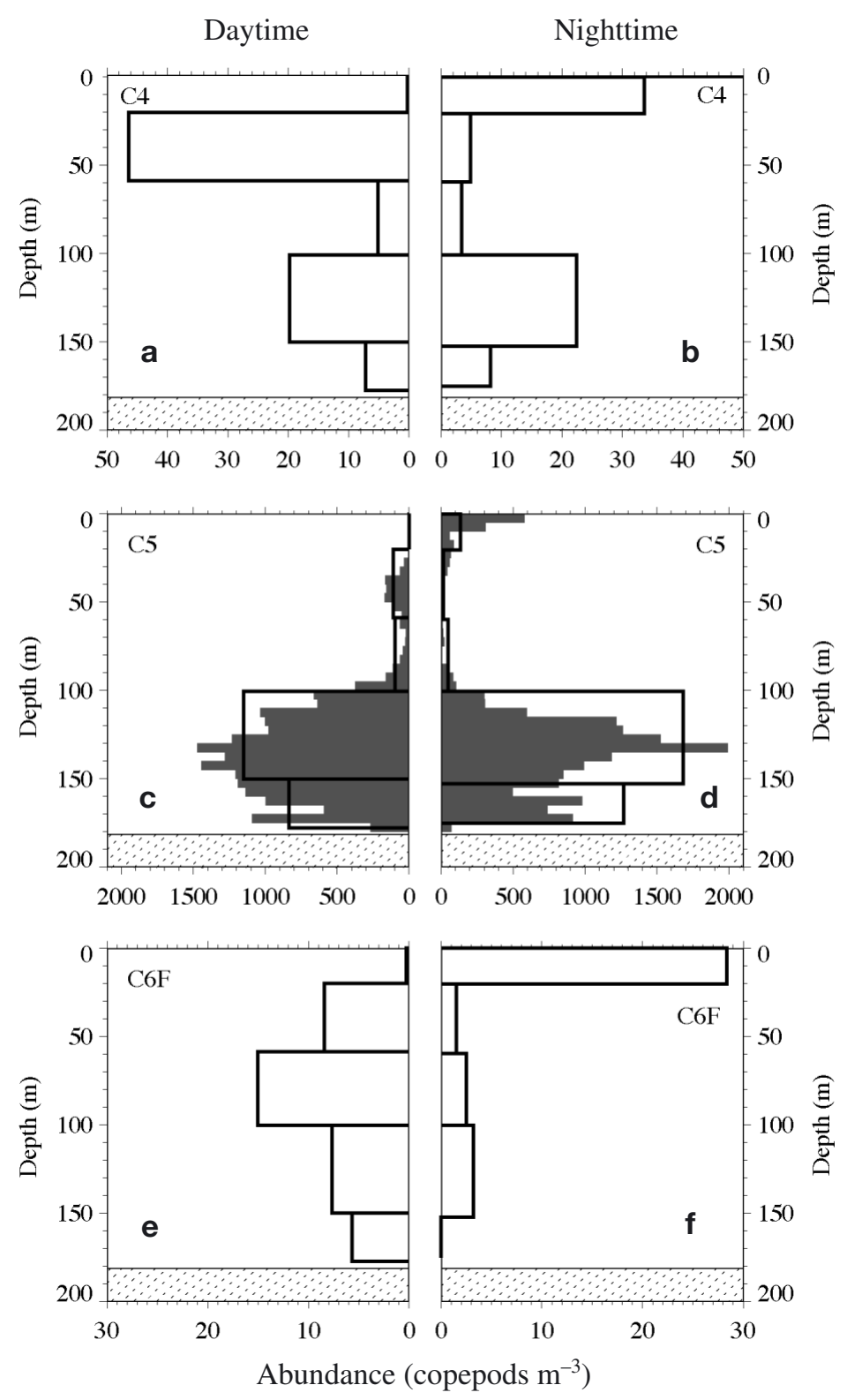

Fig. 6. Calanus finmarchicus. Vertical distribution of $(\mathrm{a}, \mathrm{b}) \mathrm{C} 4,(\mathrm{c}, \mathrm{d}) \mathrm{C} 5$ and $(\mathrm{e}, \mathrm{f})$ adult females (C6F) averaged over all daytime $(\mathrm{a}, \mathrm{c}, \mathrm{e})$ and nighttime (b,d,f) MOCNESS tows during DVM 2. (c,d) Average OPCderived, daytime and nighttime vertical distributions of C. finmarchicus C5 shown as gray bars. Bottom indicated by the hatched area

(patchiness) in C. finmarchicus C5 distribution (Fig. 5). When this outlier is removed, the correlation between right whale sighting rate and 90 to $140 \mathrm{~m} \mathrm{C}$. finmarchicus C5 abundance becomes remarkably strong and highly significant $(\mathrm{n}=9, \mathrm{r}=0.969, \mathrm{p}<0.0001)$. No significant correlations were detected between right whale sighting rate and $C$. finmarchicus $\mathrm{C} 5$ abundance computed in depth strata near the surface, the bottom or spanning the entire water column. Temporal vari- ability in right whale sighting rates at each fixed oceanographic station appeared to have similar periodicity to that of the tide. This was particularly apparent during DVM 2, when peaks in sighting rates occurred when patches of C. finmarchicus C5 at mid-water were advected past the station just before high tide (Fig. 5a,b).

\section{DISCUSSION}

A large portion of the Calanus finmarchicus C5 population in each DVM study did not migrate, but instead remained below $100 \mathrm{~m}$ throughout both day and night. Examination of the MOCNESS samples immediately after collection indicated that these non-migrating copepods had empty guts, well-developed oil sacs and were less active than individuals collected in the migrating layer. These observations indicate that the deep layer was composed of copepods in diapause. Diapause is a resting state employed by $C$. finmarchicus to survive the long period of low food availability during the summer and fall (Hirche 1996). C. finmarchicus C5 enter diapause after arresting their development and undertaking an ontogenetic vertical migration to depths where predation may be minimized (Kaartvedt 1996, Dale et al. 1999) and temperatures are low enough to ensure low rates of metabolism and oil reserve depletion (Ingvarsdóttir et al. 1999). In contrast to the diapausing $C$. finmarchicus C5, the copepods that composed the migrating layer had smaller oil sacs (ca. $33 \%$ smaller than deep animals) and food in their guts, females had mature oocytes (an indication of active spawning) and surface net and bucket samples revealed the presence of all developmental stages (nauplii, copepodites and adults). These observations indicate an actively feeding and growing population in the upper water column.

The upward vertical migration by copepods at dusk is thought to be motivated by the presence of food in the surface waters (e.g. Dagg et al. 1989, Dagg 1997). DVM may be arrested, however, when surface food resources become depleted (Dagg 1985, Durbin et al. 1995). Campbell et al. (2001) found evidence of food limitation in Calanus finmarchicus in surface waters with chlorophyll a concentrations less than $1 \mu \mathrm{g} \mathrm{l}^{-1}$, whereas $C$. finmarchicus were in much better condition and had higher egg production rates in waters with chlorophyll a concentrations of between 


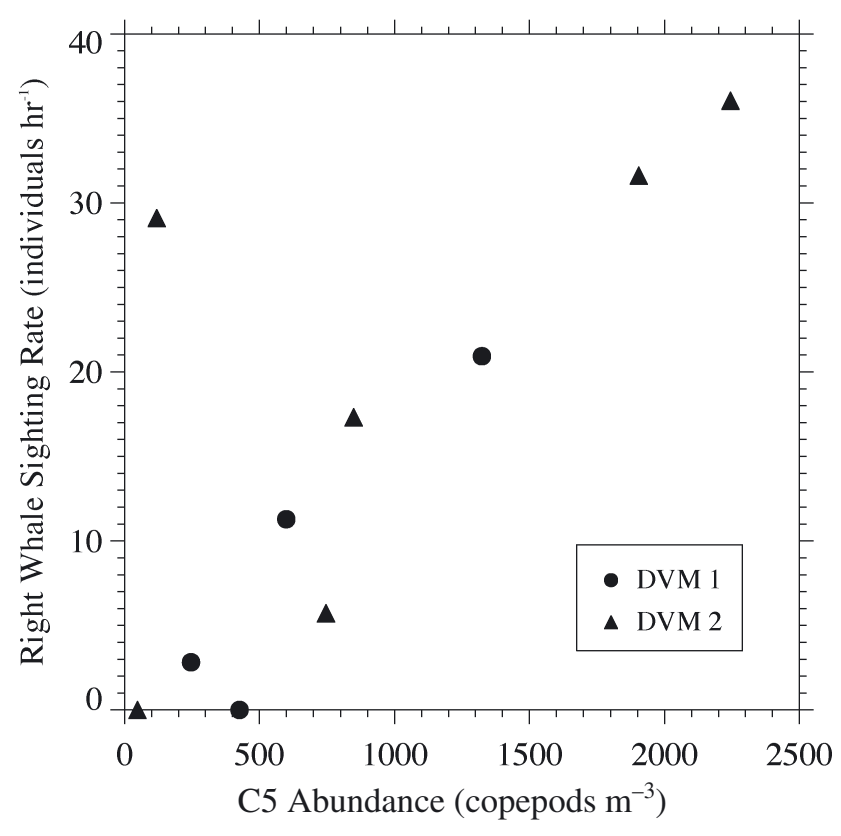

Fig. 7. Eubalaena glacialis and Calanus finmarchicus. Right whale sighting rate within $2000 \mathrm{~m}$ of the ship versus $C$. finmarchicus C5 abundance between 90 and $140 \mathrm{~m}$. (•) Observations from DVM $1 ;(\boldsymbol{\Lambda})$ observations from DVM 2

1.5 and $1.8 \mu \mathrm{g} \mathrm{l}^{-1}$. During the present study, maximum, in situ chlorophyll a concentrations in the upper $15 \mathrm{~m}$ were greater than $2 \mu \mathrm{g} \mathrm{l}^{-1}$. Moreover, the presence of all development stages, spawning females and individuals with food in their guts indicate that $C$. finmarchicus in the migrating later were not food limited to any great extent. Migration to the surface layer at dusk by C. finmarchicus is therefore likely due to the presence of abundant, exploitable food resources.

Migration out of the surface layers near dawn is widely considered to be a strategy employed by copepods to evade visual predators by seeking refuge below the euphotic zone (e.g. Bollens \& Frost 1989, Bollens et al. 1992). Several visual predators of Calanus finmarchicus occur in the lower Bay of Fundy, including euphausiids (Kulka et al. 1982), planktivorous fish (Sinclair \& Iles 1985) and seabirds (Mercier \& Gaskin 1985, Brown \& Gaskin 1988). It is possible that right whales could also utilize vision while preying on $C$. finmarchicus in the euphotic zone (Kenney et al. 2001). Despite their high, individual ingestion rates, however, predation pressure from right whales is relatively low and unlikely to influence $C$. finmarchicus DVM behavior. To illustrate this, consider the euphausiid Meganyctiphanes norvegica or northern krill, an effective visual predator of copepods (Torgersen 2001). $M$. norvegica is abundant in Grand Manan Basin (Kulka et al. 1982) and has a catholic diet that includes $C$. finmarchicus (McClatchie 1985, Båmstedt \& Karlson
1998, Lass et al. 2001, Torgersen 2001). Based on an ingestion rate of $12.5 \times 10^{4} \mathrm{~W}$ ind..$^{-1}$ (Baumgartner \& Mate 2003) or $1.6 \times 10^{9}$ copepods ind $.^{-1} \mathrm{~d}^{-1}, 150$ right whales (half of the population) would have an estimated predation rate on $C$. finmarchicus of $0.24 \times$ $10^{12}$ copepods d $\mathrm{d}^{-1}$. By comparison, $M$. norvegica would have an estimated predation rate 7.5 times that, or $1.8 \times 10^{12}$ copepods $\mathrm{d}^{-1}$, based on an average abundance of 100 ind. $\mathrm{m}^{-2}$ (Kulka et al. 1982), an ingestion rate of 1 copepod ind. ${ }^{-1} \mathrm{~h}^{-1}$ (Båmstedt \& Karlson 1998) and an approximate surface area for Grand Manan Basin of $750 \mathrm{~km}^{2}$. (The numbers upon which these predation rates are based were chosen from the maximum of their range for right whales and the minimum of their range for $M$. norvegica to provide a conservative estimate of the relative importance of right whale predation relative to that of $M$. norvegica.) Thus, visual predation by more abundant species, such as $M$. norvegica or herring Clupea harengus, is expected to have much greater influence over $C$. finmarchicus DVM than predation by right whales.

The selection of daytime depths by the migrating layer of Calanus finmarchicus may also be driven by predator avoidance. C. finmarchicus $\mathrm{C} 5$ and $\mathrm{C} 6 \mathrm{~F}$ migrated to depths between 40 and $100 \mathrm{~m}$ at dawn while $C$. finmarchicus $\mathrm{C} 4$ appeared to migrate to shallower depths of between 20 and $60 \mathrm{~m}$. Kulka et al. (1982) and Hurley et al. (1983) described the respective vertical distributions of euphausiids (Meganyctiphanes norvegica, Thysanoessa inermis and T. longicaudata) and chaetognaths (Sagiita elegans) during a DVM study in Grand Manan Basin. They reported that nearly all of the euphausiids and chaetognaths occurred below $100 \mathrm{~m}$ during net sampling at noon. Although the in situ vertical distribution of predators during the present study is unknown (the net sampling was not designed to quantitatively assess invertebrate predator abundance), C. finmarchicus may select a daytime depth stratum that is deep and dark enough to minimize visual predation, yet is shallow enough to avoid mortality caused by euphausiids and chaetognaths that are capable of raptorial predation via mechanical detection (Newbury 1972, Torgersen 2001). The daytime vertical distribution of the migrating $C$. finmarchicus also separates them from the deeper diaupausing layers of $C$. finmarchicus $C 5$ upon which right whales feed during the day (Baumgartner \& Mate 2003). However, the selection of a daytime depth that minimizes right whale predation is probably only an incidental benefit of avoidance of other, more abundant predators (see above).

Right whale daytime abundance was correlated with OPC-detected Calanus finmarchicus C5 abundance at mid-depths (90 to $140 \mathrm{~m}$ ) and Baumgartner \& Mate (2003) demonstrated that tagged right whales in the 
lower Bay of Fundy concentrated their foraging effort on deep layers of C. finmarchicus C5 below $90 \mathrm{~m}$ during the daytime. These results indicate that right whales bypass the migrating layer to feed on the deeper, diapausing $C$. finmarchicus during the day. From the perspective of an optimally foraging whale, feeding in the deeper layer has a higher energetic cost than feeding in the shallower layer because transit time to the depth of feeding is increased and thus feeding time at that depth is decreased. For example, ingestion rates would be reduced by 8 to $19 \%$ when feeding on a layer between 90 and $140 \mathrm{~m}$ (transit time of 2.1 to $3.3 \mathrm{~min}$ ) relative to feeding on an identical layer at $50 \mathrm{~m}$ (transit time of $1.2 \mathrm{~min}$ ) based on an average descent speed of $1.40 \mathrm{~m} \mathrm{~s}^{-1}$, average ascent speed of $1.47 \mathrm{~m} \mathrm{~s}^{-1}$ and average dive duration of $12.2 \mathrm{~min}$ (Baumgartner \& Mate 2003). However, when compared to the copepods in the migrating layer, the individuals that comprised the deeper diapausing layer were much more abundant, had a higher caloric content (owing to their larger oil sacs) and were less active (i.e. less able to avoid capture). Competition for these deeper C. finmarchicus from visual predators would likely be negligible as well. Thus, the energetic benefits of feeding on this deep layer probably far outweigh the relative costs.

During the night, the energetic cost of feeding on the migrating layer would be even further reduced relative to the cost of feeding on the diapausing Calanus finmarchicus because near-surface feeding entails almost no transit time at all. The low abundance of migrating animals observed near the surface during the later nighttime hours of DVM 1 and during all of the nighttime hours of DVM 2 suggests that, like during the daytime, feeding on the diapausing $C$. finmarchicus would provide the most energetic benefit. During DVM 1, however, surface concentrations of $C$. finmarchicus C5 in the early nighttime hours exceeded those found in the deeper layer (Figs. $2 \& 3$ d) and were augmented by high C. finmarchicus $\mathrm{C} 4$ concentrations (Fig. 3b). This high surface abundance may have formed from the concentration of $C$. finmarchicus spread over 40 to $100 \mathrm{~m}$ by day into a 10 to $15 \mathrm{~m}$ layer at the surface at night. Furthermore, the $C$. finmarchicus $\mathrm{C} 5$ abundance in the surface waters at this time exceeded the minimum concentrations upon which right whales have been observed feeding during the day (ca. 3000 copepods $\mathrm{m}^{-3}$; Baumgartner \& Mate 2003). Although these surface $C$. finmarchicus were of lower caloric content and were more likely to avoid capture, the decreased energetic cost of foraging at the surface and the relatively high abundance of $C$. finmarchicus suggests that this patch could have provided more energetic benefit than the deep diapausing layer. The right whale sighting rate observed just before this surface patch was encountered, however, was low (Fig. 2), which suggests that the patch may have been ephemeral or too small in size to be readily detected by the whales.

Dolphin movements and abundance have been correlated with tidal currents (e.g. Shane 1980, Parsons 1998, Mendes et al. 2002), but many of these studies document near-shore situations where small-scale tidal fronts can presumably concentrate prey and attract the dolphins (Mendes et al. 2002). In the middle of Grand Manan Basin, the tides do not produce fronts, but should instead advect passive particles in the familiar tidal ellipse (if lower frequency currents are neglected). We therefore had no expectation that temporal variability in right whale abundance around an arbitrary location would be associated with any particular phase of the tide. The observed correlations among right whale sighting rate, mid-water Calanus finmarchicus C5 abundance and within-study tidal state are likely the result of (1) advection of both predator and prey by the tides and (2) small scale (100s of $\mathrm{m}$ or less) movements by the right whales to keep them within or near prey patches. From our perspective at a fixed geographic location, the tidal currents carried the whales and the patches of $C$. finmarchicus upon which they were feeding near the station, and thus right whale and mid-water $C$. finmarchicus abundance increased. Then, as the tide turned and tidal currents advected both the whales and the patches away from the station, right whale and $C$. finmarchicus abundance decreased. During DVM 2, it appears that the same mid-water patch of $C$. finmarchicus C5 was sampled just before (and possibly just after) each high tide, and right whale abundance was high whenever the patch was present. If this was indeed a single patch observed on 3 separate occasions, then our data suggest that right whales may remain with a patch for up to a day and over spatial scales of several kilometers. Moreover, these data suggest that a patch can persist at these same temporal and spatial scales despite predation by the whales.

Acknowledgements. We appreciate the support of P. Celone (captain) and the officers and crew of NOAA RV 'Albatross IV'. Many thanks to R. Merrick and P. Clapham for procuring the ship time for us, to B. Mate for the loan of the OPC, to S. Barron, A. Durbin, S. Kumagai, J. Michaud, V. Portway and B. Welton for their able assistance in the field and to M. Casas for processing the MOCNESS samples in the lab. We are also grateful for the helpful comments of 3 anonymous reviewers. This work was supported by the National Marine Fisheries Service, Office of Naval Research and the Oregon State University Marine Mammal Endowment. M.F.B. was supported by an Earth System Science fellowship from the National Aeronautics and Space Administration during the field work and by the Postdoctoral Scholar Program at the Woods Hole Oceanographic Institution (with funding provided by the Ocean Life Institute) during manuscript preparation. 


\section{LITERATURE CITED}

Båmstedt U, Karlson K (1998) Euphausiid predation on copepods in coastal waters of the Northeast Atlantic. Mar Ecol Prog Ser 172:149-168

Baumgartner MF (2003) Comparisons of Calanus finmarchicus fifth copepodite abundance estimates from nets and an optical plankton counter. J Plankton Res 25:855-868

Baumgartner MF, Mate BR (2003) Summertime foraging ecology of North Atlantic right whales. Mar Ecol Prog Ser 264:123-135

Baumgartner MF, Cole TVN, Clapham PJ, Mate BR (2003) North Atlantic right whale habitat in the lower Bay of Fundy and on the SW Scotian Shelf during 1999-2001. Mar Ecol Prog Ser 264:137-154

Beardsley RC, Epstein AW, Chen C, Wishner KF, Macaulay MC, Kenney RD (1996) Spatial variability in zooplankton abundance near feeding right whales in the Great South Channel. Deep-Sea Res II 43:1601-1625

Bollens SM, Frost BW (1989) Zooplanktivorous fish and variable diel vertical migration in the marine planktonic copepod Calanus pacificus. Limnol Oceanogr 34:1072-1083

Bollens SM, Frost BW, Thoreson DS, Watts SJ (1992) Diel vertical migration in zooplankton: field evidence in support of the predator avoidance hypothesis. Hydrobiologia 234:33-39

Bowditch N (1995) The American practical navigator. Defense Mapping Agency Hydrographic/Topographic Center, Bethesda, MD

Brown RGB, Gaskin DE (1988) The pelagic ecology of the grey and red-necked phalaropes Phalaropus fulicarius and $P$. lobatus in the Bay of Fundy, eastern Canada. Ibis 130:234-250

Campbell RG, Runge JA, Durbin EG (2001) Evidence for food limitation of Calanus finmarchicus production rates on the southern flank of Georges Bank during April 1997. DeepSea Res II 48:531-549

Dagg MJ (1985) The effects of food limitation on diel migratory behavior in marine zooplankton. Arch Hydrobiol Beih Ergebn Limnol 21:247-255

Dagg MJ (1997) Vertical migration and feeding behavior of Calanus pacificus females during a phytoplankton bloom in Dabob Bay, U.S. Limnol Oceanogr 42:974-980

Dagg MJ, Frost BW, Walser WE Jr (1989) Copepod diel migration, feeding, and the vertical flux of pheopigments. Limnol Oceanogr 34:1062-1071

Dale T, Bagøien E, Melle W, Kaartvedt S (1999) Can predator avoidance explain varying overwintering depth of Calanus in different oceanic water masses? Mar Ecol Prog Ser 179:113-121

Durbin EG, Campbell RG, Gilman SL, Durbin AG (1995) Abundance, biomass, vertical migration and estimated development rate of the copepod Calanus finmarchicus in the southern Gulf of Maine during late spring. Contin Shelf Res 15:571-591

Durbin E, Teegarden G, Campbell R, Cembella A, Baumgartner MF, Mate BR (2002) North Atlantic right whales, Eubalaena glacialis, exposed to paralytic shellfish poisoning (PSP) toxins via a zooplankton vector, Calanus finmarchicus. Harmful Algae 1:243-251

Geraci JR, Anderson DM, Timperi RJ, St Aubin DJ, Early GA, Prescott JH, Mayo CA (1989) Humpback whales (Megaptera novaeangliae) fatally poisoned by dinoflagellate toxin. Can J Fish Aquat Sci 46:1895-1898

Herman AW (1988) Simultaneous measurement of zooplankton and light attenuance with a new optical plankton counter. Contin Shelf Res 8:205-221
Herman AW (1992) Design and calibration of a new optical plankton counter capable of sizing small zooplankton. Deep-Sea Res 39:395-415

Hirche HJ (1996) Diapause in the marine copepod, Calanus finmarchicus - a review. Ophelia 44:129-143

Hurley PCF, Corey S, Iles TD (1983) Distributional patterns of chaetognaths in the Bay of Fundy. Can J Zool 61: $2257-2265$

Ingvarsdóttir A, Houlihan DF, Heath MR, Hay SJ (1999) Seasonal changes in respiration rates of copepodite stage V Calanus finmarchicus (Gunnerus). Fish Oceanogr 8(Suppl 1):73-83

International Whaling Commission (IWC) (2001) Report of the workshop on status and trends of western North Atlantic right whales. J Cetacean Res Manage Spec Issue 2:61-87

Kaartvedt S (1996) Habitat preference during overwintering and timing of seasonal vertical migration of Calanus finmarchicus. Ophelia 44:145-156

Kenney RD, Kraus SD (1993) Right whale mortality-a correction and an update. Mar Mamm Sci 9:445-446

Kenney RD, Mayo CA, Winn HE (2001) Migration and foraging strategies at varying spatial scales in western North Atlantic right whales: a review of hypotheses. J Cetacean Res Manage Spec Issue 2:251-260

Kirk JTO (1994) Light \& photosynthesis in aquatic ecosystems, 2nd edn. Cambridge University Press, Cambridge

Knowlton AR, Kraus SD (2001) Mortality and serious injury of northern right whales (Eubalaena glacialis) in the western North Atlantic Ocean. J Cetacean Res Manage Spec Issue $2: 193-208$

Kraus SD (1990) Rates and potential causes of mortality in North Atlantic right whales (Eubalaena glacialis). Mar Mamm Sci 6:278-291

Kulka DW, Corey S, Iles TD (1982) Community structure and biomass of euphausiids in the Bay of Fundy. Can J Fish Aquat Sci 39:326-334

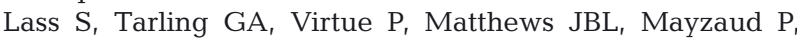
Buchholz F (2001) On the food of northern krill Meganyctiphanes norvegica in relation to its vertical distribution. Mar Ecol Prog Ser 214:177-200

Martin JL, White A (1988) Distribution and abundance of the toxic dinoflagellate Gonyaulax excavata in the Bay of Fundy. Can J Fish Aquat Sci 45:1968-1975

Mayo CA, Marx MK (1990) Surface foraging behavior of the North Atlantic right whale, Eubalaena glacialis, and associated zooplankton characteristics. Can J Zool 68: $2214-2220$

Mayo CA, Letcher BH, Scott S (2001) Zooplankton filtering efficiency of the baleen of a North Atlantic right whale, Eubalaena glacialis. J Cetacean Res Manage Spec Issue 2: 225-229

McClatchie S (1985) Feeding behaviour in Meganyctiphanes norvegica (M. Sars) (Crustacea: Euphausiacea). J Exp Mar Biol Ecol 86:271-284

Mendes S, Turrell W, Lütkebohle T, Thompson P (2002) Influence of the tidal cycle and a tidal intrusion front on the spatio-temporal distribution of coastal bottlenose dolphins. Mar Ecol Prog Ser 239:221-229

Mercier FM, Gaskin DE (1985) Feeding ecology of migrating red-necked phalaropes (Phalaropus lobatus) in the Quoddy region, New Brunswick, Canada. Can J Zool 63: 1062-1067

Murison LD, Gaskin DE (1989) The distribution of right whales and zooplankton in the Bay of Fundy, Canada. Can J Zool 67:1411-1420

Nautical Software (1996) Tides \& Currents, version 2.0, users guide, 3rd edn. Nautical Software, Beaverton, OR 
Newbury TK (1972) Vibration perception by chaetognaths. Nature 236:459-460

Parsons ECM (1998) The behaviour of Hong Kong's resident cetaceans: the Indo-Pacific hump-backed dolphin and the finless porpoise. Aquat Mamm 24:91-110

Shane SH (1980) Occurrence, movements, and distribution of bottlenose dolphin, Tursiops truncatus, in southern Texas. Fish Bull 78:593-601

Sinclair M, Iles TD (1985) Atlantic herring (Clupea harengus) distributions in the Gulf of Maine-Scotian Shelf area in relation to oceanographic features. Can J Fish Aquat Sci 42:880-887

Teegarden GJ, Campbell RG, Durbin EG (2001) Zooplankton feeding behavior and particle selection in natural assemblages containing toxic Alexandrium spp. Mar Ecol Prog Ser 218:213-226

Torgersen T (2001) Visual predation by the euphausiid Meganyctiphanes norvegica. Mar Ecol Prog Ser 209: 295-299

Townsend DW, Pettigrew NR, Thomas AC (2001) Offshore blooms of the red tide organism, Alexandrium spp., in the Gulf of Maine. Contin Shelf Res 21:347-369

Turriff N, Runge JA, Cembella AD (1995) Toxin accumulation and feeding behaviour of the planktonic copepod Calanus finmarchicus exposed to the red-tide dino-

Editorial responsibility: Kenneth Sherman (Contributing Editor), Narragansett, Rhode Island, USA flagellate Alexandrium excavatum. Mar Biol 123:55-64 Watkins WA, Schevill WE (1976) Right whale feeding and baleen rattle. J Mammal 57:58-66

Wiebe PH, Burt KH, Boyd SH, Morton AW (1976) A multiple opening/closing net and environmental sensing system for sampling zooplankton. J Mar Res 34:313-326

Wiebe $\mathrm{PH}$, Morton AW, Bradley AM, Backus RH, Craddock JE, Barber V, Cowles TJ, Flierl GR (1985) New developments in the MOCNESS, an apparatus for sampling zooplankton and micronekton. Mar Biol 87:313-323

Winn HE, Goodyear JD, Kenney RD, Petricig RO (1995) Dive patterns of tagged right whales in the Great South Channel. Contin Shelf Res 15:593-611

Wishner K, Durbin E, Durbin A, Macaulay M, Winn H, Kenney R (1988) Copepod patches and right whales in the Great South Channel off New England. Bull Mar Sci 43: 825-844

Wishner KF, Schoenherr JR, Beardsley R, Chen C (1995) Abundance, distribution and population structure of the copepod Calanus finmarchicus in a springtime right whale feeding area in the southwestern Gulf of Maine. Cont Shelf Res 15:475-507

Woodley TH, Gaskin DE (1996) Environmental characteristics of North Atlantic right and fin whale habitat in the lower Bay of Fundy, Canada. Can J Zool 74:75-84

Submitted: February 27, 2003; Accepted: September 15, 2003 Proofs received from author(s): December 2, 2003 